\title{
Evaluation of Regional Technological Innovation Capability in Guangxi Based on Factor Analysis
}

\author{
Xin Zhu \\ Department of Management, \\ Guangxi University of Science and Technology, \\ Liuzhou, P.R.China \\ 5266736@qq.com
}

\author{
Zhiqiang Li \\ Department of Management, \\ Guangxi University of Science and Technology, \\ Liuzhou, P.R.China \\ 614088601@qq.com
}

\begin{abstract}
This paper first constructs the evaluation index system of regional technological innovation capability, uses the factor analysis method to evaluate the regional technological innovation capability of our country's 30 provinces, and then compares the technological innovation ability with each other. Finally focused in Guangxi as an example, this paper analyzes and compares with other provinces in gap and the insufficiency of technical innovation ability, and puts forward the corresponding countermeasures and suggestions.
\end{abstract}

Keywords-innovation ability; factor analysis; regional innovation; index construction

\section{INTRODUCTION}

To change the mode of economic growth is the important task for China. Its essence is to transform the cost of the leading industrial advantages into industrial advantage of leading technology, realize the upgrading of industrial structure.And enhance the capability of independent innovation is the route must be took for the industrial upgrading. The cultivation of regional innovation ability has become the primary factor of regional competitive advantage. The evaluation of regional technology innovation ability is helpful to the in-depth analysis of the status of regional technological innovation, is to develop regional development policy and the implementation of scientific development guiding principle ${ }^{[1]}$.

With the establishment of the Beibu Gulf Economic Zone and the ASEAN Free Trade Area, a comprehensive evaluation and enhance the regional technological innovation capability, to promote economic development in Guangxi region has important significance. This paper uses the factor analysis method, to evaluate the technology innovation capacity of 30 provinces, and carries on the comparison to regional technology innovation ability, to understand the status of the current innovation, as well as in other parts of the gap, and puts forward the corresponding countermeasures and Suggestions.

\section{CONSTRUCITON OF EVALUATION INDEX For TECHNOLOGICAL INNOVATION CAPABILITY}

Foreign scholars focused on regional technological innovation capability in regional innovation strategy, regional planning and the transfer of technology, regional innovation policy. Domestic research focused on literature regional technological innovation capability evaluation, such as Zhang $\mathrm{Xin}^{[2]}$ puted forward by science and technology investment, $\mathrm{R} \& \mathrm{D}$ investment, investment in education, per capita production capacity, labor productivity, technological transformation capacity, the number of patents and other scientific and technological achievements output indicators to evaluate the regional technological innovation capability. Lv Yongbo $^{[3]}$ divided the area into the research and development stage of technological innovation capability, design and prototype phase, the production phase, sales stage, and the stage is set for each corresponding regional technological innovation capability indicators. Chen Yanyan ${ }^{[4]}$ studied regional technological innovation capability and set up corresponding evaluation index from four aspects of economic development, technology investment, technology for sustainable development, technical output. From the seven aspects of R\&D capabilities, production capacity, organization and management ability, marketing ability, Cao Chongxue $^{[5]}$ analyzed the evaluation index system of enterprise technology innovation capability through technology innovation capability of the composition. Dong Feng $^{[6]}$ selected 24 of the original R\&D investment intensity indicators, such as R\&D intensity of investment, innovation and ability to build a system of independent evaluation.

By summarizing research results at home and abroad, I think that, follow a comprehensive and operability evaluation principles, evaluation index is the first comprehensive description to a review of the city technology innovation capacity of the existing status and level, reflect its development direction and degree, the basis for the basis of evaluation and at the same time, by collecting the characteristics of the available quantitative data to build the city technology innovation ability evaluation indexes. According to the above principles, the author, based on extensive literature study, the city attempted to build innovation capacity evaluation system , the system consists of three components: the target layer, namely the regional technological innovation capability of the total index; rule layer, respectively, by technology innovation investment, technological innovation output capacity, technological innovation diffusion capacity, the potential ability to support the constitution; index layer is the upper index the contents of specific, composed by 14 indicators. 
TABLE I. EVALUATION INDEX OF TECHNOLOGICAL INNOVATION CAPABILITY

\begin{tabular}{|c|c|c|}
\hline $\begin{array}{c}\text { first level } \\
\text { index }\end{array}$ & second level index & Variable \\
\hline \multirow{3}{*}{$\begin{array}{l}\text { Capability of } \\
\text { innovation } \\
\text { input }\end{array}$} & $\begin{array}{l}\text { R \& D staff of full-time } \\
\text { equivalent }\end{array}$ & $\mathrm{V}_{1}$ \\
\hline & Intramural R \& D expenditure & $\mathrm{V}_{2}$ \\
\hline & $\begin{array}{l}\text { Expenditure for science and } \\
\text { technology }\end{array}$ & $\mathrm{V}_{3}$ \\
\hline \multirow{4}{*}{$\begin{array}{l}\text { Capability of } \\
\text { Innovation } \\
\text { output }\end{array}$} & The number of patents invented & $\mathrm{V}_{4}$ \\
\hline & $\begin{array}{l}\text { The amount of scientific papers } \\
\text { published }\end{array}$ & $\mathrm{V}_{5}$ \\
\hline & New product sales revenue & $\mathrm{V}_{6}$ \\
\hline & High-tech product exports & $\mathrm{V}_{7}$ \\
\hline \multirow{3}{*}{$\begin{array}{l}\text { Capability of } \\
\text { Innovation } \\
\text { diffusion }\end{array}$} & $\begin{array}{l}\text { The introduction of foreign } \\
\text { technology funds }\end{array}$ & $\mathrm{V}_{8}$ \\
\hline & $\begin{array}{l}\text { Purchase of domestic technology } \\
\text { funds }\end{array}$ & $\mathrm{V}_{9}$ \\
\hline & $\begin{array}{l}\text { The introduction of technology to } \\
\text { absorb funds }\end{array}$ & $\mathrm{V}_{10}$ \\
\hline \multirow{4}{*}{$\begin{array}{l}\text { Capability of } \\
\text { Innovation } \\
\text { support }\end{array}$} & The level of consumption & $\mathrm{V}_{11}$ \\
\hline & $\begin{array}{l}\text { The number of high-tech } \\
\text { enterprises }\end{array}$ & $\mathrm{V}_{12}$ \\
\hline & Number of R \& D institutions & $\mathrm{V}_{13}$ \\
\hline & $\begin{array}{l}\text { Number of colleges and } \\
\text { universities }\end{array}$ & $\mathrm{V}_{14}$ \\
\hline
\end{tabular}

\section{EMPIRICAL STUDY ON THE EVALUATION OF THE TECHNOLOGICAL INNOVATION CAPABILITY}

\section{A. The Sources of Data}

According to the regional technological innovation ability evaluation index system in addition to the above-selected Taiwan and Macao, Hong Kong and Tibet (Tibet due to incomplete data can not compare like with like so as not to be evaluated) outside the Mainland of China, 30 provinces and autonomous regions of the sample, in 2012 the scientific and technological activities related to data based on technological innovation capability across the studies, the paper data mainly from the "China Science and Technology Statistics Yearbook 2013" and "2013 China statistical Yearbook." To avoid the danger due to the different dimensions of the different types of data have different magnitude brought variables can not be compared with each other, this paper uses SPSS17.0 statistical analysis software to collect raw data were processed in the same direction and standardization, and the normalized correlation coefficient matrix after the estimated correlation matrix found in most of the correlation coefficients are shown to have a strong correlation between the variables, factor analysis is appropriate.

\section{B. KMO and Bartlett's Test}

KMO test sample is given a sufficient amount of measure, the partial correlation coefficient test variables is too small. Bartlett test of sphericity tests whether the correlation matrix for the unit matrix, if the unit matrix, then the model is not suitable factor.

According to Kaiser given suitability standard for factor analysis of KMO KMO> 0.9, very suitable; $0.9>\mathrm{KMO}>0.8$, suitable; $0.8>\mathrm{KMO}>0.7$, in general; $0.7>\mathrm{KMO}>0.6$ is not suitable; $\mathrm{KMO}<0.5$, unsuitable[7]. This example, $\mathrm{KMO}=$
0.829, suitable, tested by KMO; Meanwhile, Bartlett sphericity test statistic value of 739.393 , the phase of the concomitant probability Sig $=0.000<0.01$, whereby the negative correlation matrix is the matrix of the null hypothesis. show by Bartlett test of sphericity, so this fit the selected variables for factor analysis.

\section{Determining the Number of Factors}

As is seen from the analysis, the characteristic values of the first three factors were $70.156,10.580,8.24$, accumulating of 88.981 percent variance of contribution rate. According to the principle that eigenvalue is greater than 1 , the first three factors can be extracted. Cumulative contribution rate is greater than $85 \%$, indicating that these three factors can be summarized with most information of original variables. Therefore, analyzing independent innovation capability of enterprises by first three factor is appropriate.

\section{Extracting Common Factors and Naming}

In order to strengthen the common factor of the practical problems of analysis and interpretation capabilities, the first of the three main factors extracted components F1, F2 and F3 to establish the original factor loading matrix, and then choose the maximum variance orthogonal rotation, the original load factor rotation matrix to obtain rotated factor loading matrix, such as a variable associated with a factor of contact coefficient absolute great, the closer the relationship between the factor and variable.

According to result, the common factor F1 in R \& D staff of full-time equivalent (V1), R \& D Intramural Expenditure (V2), the number of patents (V4) inventions, new product sales revenue (V6), high-tech product exports (V7) high-tech enterprise number (V12), institutions of higher learning have a higher number of positive indicators load (V14), these indicators can be expressed as the innovation output efficiency factor (F1).

In the public factor F2, fiscal expenditure for science and Technology (V3), the introduction of foreign funding for Technology (V8), funds for purchasing domestic technology (V9), the introduction of technology absorption (V10) index funds with higher normal load, these indices represents innovation input intensity factor (F2).

In the public factor F3, scientific papers published volume (V5), research and Development Agency (V13), the number of residents' consumption level (V11) index has higher normal load, these indicators can represent innovation support factor (F3).

\section{E. Calculation of Each Factor Score and Comprehensive Factor Score}

Obtained from Thomson regression factor score coefficient matrix, according to the factor score coefficient matrix can be obtained by a linear combination of the principal component of each index variable expression. The result is shown in Table $\mathrm{II}^{[8]}$. 
TABLE II. COMPONENT SCORE COEFFICIENT MATRIX

\begin{tabular}{|l|l|l|l|}
\hline & \multicolumn{3}{|c|}{ component } \\
\hline & 1 & 2 & 3 \\
\hline $\begin{array}{l}\text { R \& D staff of full-time } \\
\text { equivalent }\end{array}$ & 0.234 & -0.116 & 0.013 \\
\hline $\begin{array}{l}\text { Intramural R \& D } \\
\text { expenditure }\end{array}$ & 0.105 & -0.034 & 0.110 \\
\hline $\begin{array}{l}\text { Expenditure for science and } \\
\text { technology }\end{array}$ & -0.010 & -0.034 & 0.065 \\
\hline $\begin{array}{l}\text { The number of patents } \\
\text { invented }\end{array}$ & 0.060 & -0.037 & 0.175 \\
\hline $\begin{array}{l}\text { The amount of scientific } \\
\text { papers published }\end{array}$ & -0.183 & 0.038 & 0.406 \\
\hline New product sales revenue & 0.206 & 0.15 & -0.130 \\
\hline High-tech product exports & 0.196 & 0.025 & -0.151 \\
\hline $\begin{array}{l}\text { The introduction of foreign } \\
\text { technology funds }\end{array}$ & 0.014 & 0.194 & -0.072 \\
\hline $\begin{array}{l}\text { Purchase of domestic } \\
\text { technology funds }\end{array}$ & -0.091 & 0.341 & -0.143 \\
\hline $\begin{array}{l}\text { The introduction of } \\
\text { technology to absorb funds }\end{array}$ & -0.119 & 0.365 & -0.126 \\
\hline The level of consumption & -0.298 & 0.351 & 0.162 \\
\hline $\begin{array}{l}\text { The number of high-tech } \\
\text { enterprises }\end{array}$ & 0.305 & -0.101 & -0.135 \\
\hline $\begin{array}{l}\text { Number of R \& D } \\
\text { institutions }\end{array}$ & -0.023 & -0.226 & 0.477 \\
\hline $\begin{array}{l}\text { Number of colleges and } \\
\text { universities }\end{array}$ & 0.307 & -0.287 & 0.069 \\
\hline We score the 30 & & & \\
\hline
\end{tabular}

We score the 30 provinces and autonomous regions nationwide technology innovation ability, with the variance of each main factor after rotating the contribution rate (Table 3) as the weights of the linear weighted summation, calculate the comprehensive score and ranking of public factor, and its overall score formula is as follows:

$$
K=37.251 \% F 1+30.026 \% F 2+21.704 \% F 3
$$

Comprehensive score can be calculated according to the function of the factor scores and the total score. Overall score of each factor and composite score, each factor score, and rank of total score are shown in Table III.

\section{ANALYSIS OF EVALUATION RESUlts}

\section{A. Analysis of National Regional Technological Innovation Capability}

From TableIII, the technological innovation capability is better than the whole eastern part of central, western and northeastern regions, ranking in the top 10 in seven provinces in the eastern region, the first six are in the eastern provinces. In addition to Hainan, technological innovation capability of living in most of the eastern region above the national average, which shows strong economic growth momentum and rapid economic growth in eastern regions, indicating that economic growth and technological innovation capability is closely related. From a comprehensive index, technological innovation capability in the order of ranking of the four regions in eastern, northeastern, central, and western; the factor index, in terms of output efficiency, investment and innovation potential strength of three scores on the east are in a leading position. There are some significant differences between the central, western and northeastern regions. Output efficiency, superior to the Northeast Central Northeast than west; investment strength, superior Midwest Northeast; central innovation support than the northeast, northeast than the western, central and eastern part of the gap is not between the West and other regions! the gap between the very obvious.

\section{B. Analysis of the Technological Innovation Capability in Guangxi}

Composite score from the perspective of the main factors, technological innovation capability of Guangxi ranked No. 22 in the country.There is a big gap compared with Jiangsu, Guangdong, Beijing, Shanghai and other developed provinces . Innovation output efficiency factor is principal component in the regional technological innovation ability evaluation. Guangxi ranked No. 14 in 30 provinces .But with the ranking of Guangdong, Jiangsu and other provinces there is a big gap. It shows that the efficiency of innovation output in Guangxi region in the national rankings, although the middle level, but the actual effect of its innovative output efficiency is not ideal. Factor variance contribution rate of $30.026 \% 2$, technological innovation ability evaluation of the second principal component, Guangxi region ranked No. 27 in 30 provinces in terms of innovation input intensity, indicating that innovation Guangxi region into low intensity. Factor variance contribution rate of $21.704 \% 3$ is independent innovation capability evaluation of the third component; Guangxi enterprises ranked No. 15 in support of innovation, technological innovation show Guangxi region have some potential.

\section{The Suggestions of Results}

For this paper, the author proposes the following recommendations to improve the technological innovation capability for Guangxi:

The efforts should be intensified in order to protecting innovation achievement and improving the efficiency of innovation output. Guangxi should further improve the protection of intellectual property and patent system and create incentives and a full-service system for intellectual property protection and patent applications, continue to strengthen the protection of intellectual property and patent awareness of R \& D personnel, guide enterprises to actively carry out scientific and technological innovation and patent applications, enables companies to achieve a virtuous cycle in the patent application, new product development and intellectual property rights and other aspects of the conversion $^{[9]}$.

It must optimize the environment construction of enterprise innovation, increase enterprise innovation investment intensity. Guangxi should optimize the spatial distribution of regional economic development for innovative companies to provide a favorable external environment in terms of human resources, capital, platforms and policies. Guangxi relevant departments should increase investment in $\mathrm{R}$ \& D funding for the establishment of government-led investment, business investment in long-term mechanism to increase yuan investment, broad participation of social capital, to break the bottleneck of independent innovation funds ${ }^{[10]}$. 
Guangxi should increase the domestic and international science and technology cooperation and exchanges, especially to strengthen the digestion and absorption of innovation technology introduction. Meanwhile, government procurement policy should support the development of independent innovation and high-tech industry.

\section{REFERENCES}

[1] Zhang Jing Qiang,"Evaluation of regional technology innovation ability ”,Science and Technology Management Research,2010,5,pp.1619

[2] Zhang Xin, "Comparative analysis of the knowledge economy development in five provinces”, Science and Technology Management Research,2001,1,pp.35-38

[3] Lv Yong Bo , Hu Li Cheng,"Regional technology innovation optimization and evaluation ", China Science and Technology Forum,2000,2,pp.26-29

[4] Chen Yan Yan, “ Evaluation system of regional technology innovation Ability and regional differences research”,China Soft Science, 2005,3,pp.92-93
[5] Cao Chong Yan, Wang Huai Xue, “ Study of assessment index of Innovation Capacity of enterprises technology”,Forecast,2007,2,pp.6668

[6] Dong Feng, "The evaluation of the enterprises technology innovation ability based on factor analysis”, China Soft Science, 2008,22,pp.98102

[7] Zhang hong Po, Spss for Statistical analysis and practical Collection, 2012,pp.267-268

[8] Zhang Hong Cai, "Analysis of the technological innovation capacity of Beijing manufacturing industry”,China Science And Technology Forum,2008,7,pp.41-44

[9] Chen Rui, “The appraisal on independent innovation capability of stateowned enterprises_an example of Sichuan province”, China Soft Science, 2009,3,pp.64-65

[10] Peng Ben Hong , Luo Ming Wu,“Assessment of the indicators and methods research of independent innovation capacity of Manufacturing Enterprise ”,Modern Management Science,2008,3,pp.52-53

TABLE III. COMPRISON OF FACTOR SCORES OF PROVINCES

\begin{tabular}{|c|c|c|c|c|c|c|c|c|}
\hline \multirow[b]{2}{*}{ City } & \multicolumn{2}{|c|}{$\begin{array}{l}\text { Innovation output } \\
\text { efficiency factor }\end{array}$} & \multicolumn{2}{|c|}{$\begin{array}{c}\text { Innovation input intensity } \\
\text { factor }\end{array}$} & \multicolumn{2}{|c|}{$\begin{array}{c}\text { Innovation support } \\
\text { factor }\end{array}$} & \multicolumn{2}{|c|}{ Composite score } \\
\hline & $F_{1}$ & Sequence & $\mathrm{F}_{2}$ & Sequence & $\mathrm{F}_{3}$ & Sequence & Composite & Sequence \\
\hline Jiangsu & 2.4719 & 2 & 1.9988 & 2 & -0.3015 & 17 & 1.4556 & 1 \\
\hline Guangdong & 3.6304 & 1 & -0.0159 & 11 & 0.1344 & 10 & 1.3768 & 2 \\
\hline Shanghai & -1.2666 & 30 & 4.1847 & 1 & 0.3355 & 8 & 0.8575 & 3 \\
\hline Beijing & -0.8442 & 29 & -0.0165 & 12 & 4.6515 & 1 & 0.6902 & 4 \\
\hline Shandong & 1.1645 & 3 & 0.4051 & 6 & 0.4296 & 7 & 0.6487 & 5 \\
\hline Zhejiang & 0.7552 & 4 & 0.6019 & 4 & 0.2262 & 9 & 0.5111 & 6 \\
\hline Liaoning & -0.2419 & 15 & 0.2110 & 8 & 0.5215 & 3 & 0.0864 & 7 \\
\hline Hubei & 0.3359 & 7 & -0.6924 & 25 & 0.4935 & 4 & 0.0243 & 8 \\
\hline Fujiang & -0.0690 & 12 & 0.4357 & 5 & -0.5114 & 25 & -0.0059 & 9 \\
\hline Sichuang & 0.2404 & 10 & -0.7103 & 26 & 0.4766 & 5 & -0.0203 & 10 \\
\hline Anhui & 0.3530 & 6 & -0.3518 & 18 & -0.2136 & 16 & -0.0205 & 11 \\
\hline Hunan & 0.3242 & 8 & -0.5812 & 21 & 0.0947 & 12 & -0.0332 & 12 \\
\hline Tianjin & -0.6546 & 24 & 0.9844 & 3 & -0.3931 & 21 & -0.0336 & 13 \\
\hline Henan & 0.5516 & 5 & -0.7372 & 29 & -0.1267 & 14 & -0.0434 & 14 \\
\hline Hebei & 0.2966 & 9 & -0.6793 & 24 & -0.3981 & 22 & -0.1799 & 15 \\
\hline Shanxi & -0.1693 & 13 & -0.7349 & 28 & 0.4534 & 6 & -0.1853 & 16 \\
\hline Chongqing & -0.3742 & 18 & 0.2999 & 7 & -0.8197 & 27 & -0.2272 & 17 \\
\hline Heilongjiang & -0.3324 & 17 & -0.8661 & 30 & 0.6448 & 2 & -0.2439 & 18 \\
\hline Shanxi & -0.2871 & 16 & -0.6135 & 23 & 0.1055 & 11 & -0.2683 & 19 \\
\hline Jiangxi & -0.0609 & 11 & -0.6052 & 22 & -0.3087 & 18 & -0.2714 & 20 \\
\hline Jilin & -0.3872 & 19 & -0.5079 & 20 & -0.0491 & 13 & -0.3074 & 21 \\
\hline Guangxi & -0.2006 & 14 & -0.7254 & 27 & -0.1811 & 15 & -0.3318 & 22 \\
\hline Yunnan & -0.3881 & 20 & -0.3447 & 17 & -0.4184 & 23 & -0.3389 & 23 \\
\hline Gunsu & -0.6530 & 23 & -0.0135 & 10 & -0.5053 & 24 & -0.3570 & 24 \\
\hline Neimenggu & -0.6784 & 25 & -0.1664 & 15 & -0.3295 & 19 & -0.3742 & 25 \\
\hline Guizhou & -0.4327 & 21 & -0.3659 & 19 & -0.6718 & 26 & -0.4169 & 26 \\
\hline Xinjiang & -0.6436 & 22 & -0.3426 & 16 & -0.3579 & 20 & -0.4203 & 27 \\
\hline Hainan & -0.7677 & 26 & -0.0743 & 14 & -0.9536 & 28 & -0.5153 & 28 \\
\hline Ningxia & -0.8412 & 28 & 0.0438 & 9 & -0.9984 & 29 & -0.5169 & 29 \\
\hline Qinghai & -0.8312 & 27 & -0.0201 & 13 & -1.0293 & 30 & -0.5390 & 30 \\
\hline
\end{tabular}

